\title{
PEMBELAJARAN MENYIMAK APRESIATIF CERITA PENDEK DENGAN STRATEGI BELAJAR KOOPERATIF
}

\author{
Nurhidayati \\ Fakultas Sastra Universitas Negeri Malang \\ email: nurhid1@yahoo.com
}

\begin{abstract}
This study aimed to describe the improvement in the learning of appreciative short-story listening through a cooperative learning strategy. It employed an action research design. The data were those of the implementation of the learning of appreciative listening, which included pre-listening, listening, and post-listening stages. The data collecting instruments consisted of an observation guide, accompanied by a tape recorder and field notes, and a rubric for the analysis of the appreciative listening results. The findings showed that the cooperative learning strategy was effective in the whole learning process of listening. The students attained a mean of 91.6 (very good) at the end of Cycle I and a mean of 93 (very good) at the end of Cycle II.
\end{abstract}

Keywords: learning, appreciative listening, cooperative learning strategy

\section{PENDAHULUAN}

Pembelajaran menyimak di Jurusan Sastra Arab khususnya untuk menyimak apresiatif jarang dilakukan. Hal ini terkait dengan aspek kemampuan siswa yang masih mempunyai kemampuan penguasaan kosakata rendah, dan juga terkait dengan kemampuan dosen dalam menciptakan dan mempersiapkan srategi pembelajaran yang dapat mengaktifkan dan mendorong mahasiwa bekerja sama dengan teman sekelas. Hal ini diperlukan karena mengingat kemampuan dasar berbahasa Arab siswa yang bervariasi, diperlukanlah strategi pembelajaran yang dapat menciptakan suasana pembelajaran yang dapat menciptakan kerja sama antar mahasiswa saling berkolaborasi, dan melakukan sharing dan sumbang saran dalam diskusi.

Untuk menyimak materi yang bersifat kesusastraan, maka tujuan dan prinsip-prinsip pembelajaran sastra harus dipertimbangkan. Rozaq (2001:1) menyatakan bahwa tujuan pengajaran sastra adalah agar pebelajar mampu menikmati, memahami, dan memanfaatkan karya sastra untuk mengembangkan kepribadian, memperluas wawasan kehidupan serta meningkatkan pengetahuan, dan kemampuan berbahasa.

Mahasiswa sebagai subyek yang mempelajari karya sastra hendaknya memahami fungsi karya sastra yang dipelajarinya. Adapun fungsi karya sastra bagi pembaca atau penyimak adalah sebagai (1) bayang-bayang realitas yang dapat menghadirkan gambaran dan refleksi berbagai permasalahan dalam kehidupan, (2) sumber pemahaman tentang berbagai gambaran manusia, peristiwa, dan kehidupan pada umumnya, (3) wahana memahami berbagai bentuk peristiwa di masa lalu, sekarang, dan yang akan datang, (4) wahana untuk memahami terdapatnya berbagai perbedaan baik ditinjau dari keberadaan manusia sebagai individu maupun sosial, suku maupun bangsa, (5) pengantar memahami hakikat kehidupan dan kematian, penderitaan dan kegembi- 
raan, kegagalan dan keberhasilan, serta berbagai bentuk gejolak emosional lain yang akrab dengan kehidupan manusia, dan (6) wahana untuk menciptakan dialog, diskusi, dan tanggapan-tanggapan personal tentang isu-isu dalam kehidupan sosial, masyarakat, baik melalui komunikasi lisan maupun tulisan.

Pembelajaran cerita pendek yang baik di dalam kelas harus mencerminkan dinamika kelas yang hidup. Pebelajar diharapkan senantiasa melakukan eksploitasi makna sastra baik secara individu maupun secara kolaborasi, disamping itu pebelajar juga diharapkan senantiasa melakukan sumbang saran (brainstorming)dalam berdiskusi. Aminuddin (2000:50-51) menjelaskan bahwa pembelajaran sastra di kelas harus memenuhi persyaratan sebagai berikut. (1) ditandai adanya aktifitas membaca/menyimak karya sastra baik dilakukan oleh dosen atau mahasiswa, (2) dosen harus menciptakan kelas pembelajaran sastra sebagai sebuah bentuk hubungan sosial kemanusiaan sehingga terjadi dialog antara mahasiswa dengan mahasiswa dan dosen dengan mahasiswa, (3) dosen tidak lagi menggurui tetapi memberi kesempatan kepada mahasiswa untuk menyampaikan pendapatnya secara variatif, baik secara lisan maupun tulisan. Selanjutnya Aminuddin menyatakan bahwa dalam pembelajaran sastra penciptaan kelas yang dinamis akan mendorong adanya aktifitas pebelajar satu sama lain, yaitu saling menceritakan pengalaman dan pemahaman setelah menyimak, bekerja sama dalam membentuk pemahaman dan membuat kesimpulan, bertukar pikiran dalam memberikan penilaian, dan bekerja sama dalam memberikan komentar terhadap karya sastra.

Pemahaman karya sastra secara cermat akan menghasilkan pemahaman yang tepat. Luxemburg (1987:17) menyatakan bahwa kecermatan penyimak atau pembaca sastra terhadap karya sastra akan membawa pada interpretasi yang tepat. Interpretasi seseorang terhadap karya sastra akan berbeda dengan yang lain karena jenis dan sifat teks sastra, skemata pembaca/penyimak dan tingkat publikasi sastra dalam masyarakat. Purwa (1997:12) menyatakan bahwa pemahaman karya sastra harus melibatkan alat indera, yakni pemahaman dengan menghayati atau menikmati keindahan yang memercik dari teks, percikan makna tidak hanya mengemukakan rentetan kata tetapi juga dari jalinan makna yang tersingkap dari teks sastra.

Penelitian ini memanafaatkan strategi belajar kooperatif khususnya yang menggunakan Metode Struktural dengan teknik Think Pair Share. Pendekatan ini dikembangkan oleh Spencer Kager dkk. Yang mempunyai penekanan pada penggunaan struktur tertentu yang dirancang untuk mempengaruhi pola interaksi mahasiswa. Berbagai struktur tersebut dikembangkan oleh Kagan dengan maksud agar menjadi alternatif dari berbagai struktur kelas yang lebih tradisional, seperti metode resitasi, yang ditandai dengan pengajuan pertanyaan oleh dosen kepada seluruh mahasiswa dalam kelas dan para mahasiswa memberikan jawaban setelah lebih dahulu mengangkat tangan dan ditunjuk oleh dosen. Ada struktur yang mempunyai tujuan umum untuk meningkatkan penguasaan kompetensi tertentu yang disebut Think - Pair Share, dan ada pula struktur yang tujuannya untuk mengajarkan keterampilan sosial yang disebut Active Listening dan Time Tokens

Metode Think-Pair-Share dikembangkan oleh Frank Lyman dan kawan-kawannya dari Universitas Maryland yang mampu mengubah asumsi bahwa metode resitasi dan diskusi perlu diselenggarakan dalam setting kelompok kelas secara keseluruhan. Metode Think-Pair -Share memberikan kepada 
para siswa waktu untuk berpikir dan merspons serta saling bantu satu sama lain. Sebagai contoh, seorang guru baru saja menyelesaikan suatu sajian pendek atau para siswa telah selesai membaca atau menyimak suatu tugas. Selanjutnya guru/dosen meminta kepada para siswa untuk menyadari secara lebih serius mengenai apa yang telah disimak atau dijelaskan kepadanya. Adapun langkah-langkah pembelajarannya adalah sebagai berikut.

1) Langkah 1 - Berpikir (Thinking): Guru mengajukan pertanyaan atau isu yang terkait dengan pelajaran dan siswa diberi waktu satu menit untuk berpikir sendiri mengenai jawaban atau isu tersebut.

2) Langkah 2- Berpasangan (Pairing): Selanjutnya guru meminta kepada siswa untuk berpasangan dan mendiskusikan mengenai apa yang telah dipikirkan. Interaksi pada periode ini dapat menghasilkan jawaban bersama jika suatu pertanyaan telah diajukan atau penyampaian ide bersama jika suatu isu khusus telah diidentifikasi. Waktu yang diberikan sekitar 4-5 menit.

3) Langkah 3 - Berbagi (Sharing): Pada langkah akhir ini guru meminta pasangan-pasangan tersebut untuk berbagi atau bekerja sama dengan kelas secara keseluruhan mengenai apa yang telah mereka bicarakan. Pada langkah ini akan menjadi efektif jika guru berkeliling kelas dari pasangan yang satu ke pasangan yang lain, sehingga separo atau semua pasangan memperoleh kesempatan untuk melaporkan hasil kerjanya (Nurhadi, dkk. 2004).

Masalah umum yang dikaji dalam penelitian ini adalah bagaimana implementasi pembelajaran menyimak apresiatif cerita pendek dengan strategi belajar kooperatif. Adapun masalah khusus yang dikaji dalam penelitian ini adalah: (1) bagaimana efektivitas pembelajaran menyimak apresiatif cerita pendek dengan strategi belajar kooperatif pada tahap pra-menyimak, (2) bagaimana efektivitas pembelajaran menyimak apresiatif cerita pendek dengan strategi belajar kooperatif pada tahap saat menyimak, dan (3) bagaimana efektivitas pembelajaran menyimak apresiatif cerita pendek dengan strategi belajar kooperatif pada tahap pasca-menyimak.

\section{METODE}

Jenis penelitian yang digunakan dalam penelitian ini adalah penelitian tindakan, sebagaimana disarankan oleh Kemmis dan MC. Taggart (1988:9-15) bahwa proses penelitian tindakan adalah dimulai dari tahap perencanaan, pelaksanaan tindakan, pengamatan (observasi), sampai pada tahap refleksi (perenungan, pemikiran, dan evaluasi). Sesuai dengan prinsip umum penelitian tindakan, setiap tahapan dan siklusnya dilakukan secara partisipatoris dan kolaboratif antara peneliti dan pengajar mata kuliah.

Subjek penelitian adalah 20 mahasiswa peserta matakuliah Menyimak I pada ofering A dan dosen pembina matakuliah Menyimak I di Jurusan Sastra Arab Fakultas Sastra Universitas Negeri Malang yang sedang melaksanakan interaksi belajar mengajar menyimak di laboratorium.

Data penelitian ini berupa hasil pengamatan, catatan lapangan, dan dokumentasi dari hasil kerja mahasiswa dalam mengerjakan tugas menyimak apresiatif secara berkelompok. Data penelitian berupa:

a. data aktifitas dosen dalam menerapkan strategi belajar kooperatif dalam pembelajaran menyimak apresiatif dengan materi cerita pendek untuk mengungkapkan unsur-unsur cerita pendek yang diajarkannya, dan 
b. data aktifitas mahasiswa dalam menyimak apresiatif terhadap materi cerita pendek dengan strategi belajar kooperatif untuk mengungkapkan unsur-unsur cerita pendek yang disimaknya.

Instrumen yang digunakan untuk mengumpulkan data dalam penelitian ini adalah instrumen utama dan instrumen penunjang. Instrumen utama adalah peneliti sendiri yang memiliki kemampuan untuk mengumpulkan, menyeleksi, menilai, menyimpulkan, dan menentukan data. Sebagaimana dikatakan oleh Bogdan \&Biklen (1982:28) bahwa diri peneliti sendiri yang berada di tengah-tengah latar penelitian merupakan instrumen utama. Instrumen penunjang berupa pedoman observasi, catatan lapangan, dan pedoman studi dokumentasi (Moleong, 2000). Pedoman observasi digunakan untuk mengumpulkan data tentang proses pembelajaran, baik data dosen maupun mahasiswa. Pedoman observasi berupa daftar isian chek. Catatan lapangan digunakan untuk mendeskripsikan segala yang terjadi dalam proses pembelajaran, mencatat refleksi terhadap data proses pembelajaran berupa pemikiran, pendapat, atau penafsiran data penelitian. Data dokumentasi dari presentasi kelompok berupa hasil tugas menyimak apresiatif pada setiap tahap pembelajaran dan secara menyeluruh.

Analisis data dilakukan dengan menggunakan teknik analisis data kualitatif. Analisis data dalam penelitian tindakan merupakan usaha peneliti untuk memaknai data sehingga mencapai pemahaman yang baik berkaitan dengan apa yang terjadi dalam situasi nyata (MC. Niff, 1992:85). Proses analisis data dimulai dengan menelaah seluruh data, melakukan reduksi data, menyusunnya dalam satuan-satuan, dengan mengkategorisasikannya. Hal ini dilakukan dengan mengacu pada teknik analisis data model mengalir sebagaimana yang dikemukakan oleh Miles dan Huberman (1992:18). Proses analisis data dilakukan sejak awal data terkumpul, selama pengumpulan data, dan sesudah pengumpulan data. Tahap analisis tersebut dilakukan secara berulang-ulang pada saat data terkumpul dalam setiap siklus tindakan. Ada empat jenis data yang akan dianalisis yaitu: (1) data perencanaan yang disiapkan oleh dosen, (2) data tampilan dosen dalam melaksanakan pembelajaran menyimak apresiatif, (3) data aktivitas mahasiswa dalam setiap tahap menyimak, yaitu pada tahap pramenyimak, saat menyimak, dan pascamenyimak, (4) data hasil kerja/tugas mahasiswa secara utuh dalam proses menyimak apresiatif terhadap materi berupa cerita pendek.

Adapun teknik analisis terhadap sejumlah data tersebut adalah sebagai berikut. Data perencanaan dosen dianalisis secara kualitatif. Data tampilan dosen dalam melaksanakan pembelajaran menyimak apresiatif dianalisis secara kualitatif. Data aktifitas mahasiswa dalam proses pembelajaran menyimak dianalisis secara kualitatif dan kuantitatif. Data hasil kerja/tugas mahasiswa secara menyeluruh dianalisis secara kuantitatif.

Menguji keabsahan data dimaksudkan sebagai proses mendapatkan derajat kesahihan selama proses analisis. Di dalam penelitian tindakan ini validasi data dilakukakan dengan cara (1) peninjauan kembali catatan lapangan, (2) konsultasi dengan tenaga ahli, teman sejawat, dan dosen pembina mata kuliah menyimak, dan (3) trianggulasi yaitu dengan cara memperoleh kevalidan data tentang latar, pelaku, setting, alur, dan proses yang terjadi selama pembelajaran dari tiga sudut pandang yang berbeda yaitu dosen, peneliti, dan ma- 
hasiswa, sebagaimana yang disarankan oleh MC Niff (1992).

\section{HASIL DAN PEMBAHASAN \\ Pembelajaran Menyimak Apresiatif Cerita Pendek dengan Strategi Belajar Kooperatif Siklus I}

Sebelum melaksanakan tindakan, peneliti dengan dosen mata kuliah menyimak di Jurusan Sastra Arab Fakultas Sastra secara kolaboratif menyusun rencana pembelajaran. Perencanaan tersebut disusun dan dikembangkan berdasarkan tujuan pembelajaran menyimak yang tertuang dalam katalog Jurusan Sastra Arab Fakultas Sastra tahun 2003. Perencanaan pembelajaran tersebut terdiri atas (1) menetukan tujuan pembelajaran, (2) memilih materi, (3) menentukan kegiatan belajar mengajar, dan (4) menyusun alat penilaian.

Proses pembelajaran ini mengambil tujuan pembelajaran umum mengapresiasi cerita pendek terhadap tokoh-tokoh cerita, alur, latar, dan suasana. Alokasi waktu adalah 2 jam pertemuan (80 menit) yang difokuskan pada kegiatan pramenyimak,menyimak, dan pascamenyimak. Berdasarkan tujuan pembelajaran umum tersebut, peneliti dan dosen menetapkan tujuan pembelajaran khusus.

Rancangan pembelajaran menyimak apresiatif cerita pendek dengan strategi belajar kooperatif siklus I yang dibagi menjadi 3 tahapan, yaitu tahap pra-menyimak, menyimak, dan pasca menyimak dapat dilihat pada lampiran. Ketiga tahapan ini tidak berdiri sendiri tetapi saling terkait. Rencana kegiatan belajar mengajar dalam pembelajaran ini terdiri atas rencana kegiatan dosen dan mahasiswa.

Materi yang diajarkan pada siklus I adalah Cerita pendek yang berjudul "Putri Salju". Cerita pendek tersebut didokumentasikan dalam bentuk
CD tersebut bertema tentang keserakahan/ akhlak tercela seorang permaisuri. Metode pembelajaran yang digunakan adalah strategi belajar kooperatif dengan teknik Think Pair-Share. Metode ini digunakan agar setelah para mahasiswa menonton cerita mereka mengapresiasi cerita tersebut melalui Lembar Kerja Siswa masing-masing, kemudian mereka diminta secara berpasangan mendiskusikan hasil kerja mereka, setelah itu setiap pasangan tersebut bebas berdiskusi dengan teman sekelas untuk membahas hasil kerja mereka dengan pasangan masing-masing.

Evaluasi pembelajaran yang direncanakan adalah evaluasi proses dan hasil. Evaluasi proses yang direncanakan, yaitu mengikuti aktivitas mahasiswa secara individu maupun kelompok dalam melaksanakan kegiatan. Evaluasi proses dilaksanakan dalam setiap proses apresiasi dengan menggunakan pedoman observasi dan catatan lapangan untuk mengetahui proses kerja mahasiswa, dan hasil sementara kerja apresiasi mahasiswa dalam menyimak. Evaluasi hasil dilaksanakan untuk mengetahui hasil perolehan mahasiswa baik secara individual maupun kelompok yang berupa tes esei dalam Lembar Kerja

Pelaksanaan pembelajaran menyimak apresiatif cerpen dengan strategi belajar kooperatif di Jurusan Sastra Arab Universitas Negeri Malang untuk siklus I dilaksanakan pada hari Senin, tanggal 25 September 2006 pukul 11.00 -12.20. Sesuai dengan perencanaan yang telah diuraikan di atas, pelaksanaan pembelajaran terbagi atas tiga tahap, yaitu tahap pra-menyimak, menyimak, dan pascamenyimak.

Keberhasilan tindakan siklus I diamati selama proses pelaksanaan tindakan dan setelah tindakan. Fokus pengamatan adalah perilaku 
dosen dan mahasiswa dengan menggunakan pedoman observasi dan catatan lapangan. Adapun aspek yang diamati adalah aktivitas dosen dan mahasiswa dalam proses pembelajaran yang terdiri atas 3 tahapan, yaitu tahap pramenyimak, menyimak, dan pascamenyimak.

Secara umum, pembelajaran pada siklus I sudah menunjukkan keberhasilan. Hal ini terlihat pada nilai rata-rata mahasiswa yang tinggi, yaitu: 91,6 (sangat baik). Setelah melihat hasil pembelajaran di atas, peneliti dan dosen menyimpulkan bahwa pembelajaran pada siklus I ini masih kurang sempurna mengingat kegiatan presentasi hasil kerja belum dilaksanakan. Namun dengan melihat hasil kerja mahasiswa yang memperoleh nilai rata-rata yang sangat tinggi, maka perbaikan rancangan pembelajaran hanya dilakukan dengan menambahkan waktu untuk kegiatan pascamenyimak atau diskusi hasil dan presentasi. Kegiatan siklus II dimaksudkan untuk memantapkan apakah nilai yang diperoleh mahasiswa dapat stabil atau tidak, sehingga masih perlu refleksi untuk dipergunakan pada siklus II.

Berdasarkan hasil observasi tentang aktivitas pembelajaran menyimak apresiatif ada siklus I, dosen telah mempersiapkan rancangan perkuliahan yang didiskusikan bersama dengan peneliti, pada kegiatan pramenyimak dosen menjelaskan tujuan pembelajaran, serta membangkitkan skemata mahasiswa sambil bertanya jawab. Dosen dapat menarik minat mahasiswa dengan bertanya jawab tentang judul cerita. Dosen menayangkan cerita yang sudah disiapkan. Kegiatan selanjutnya dosen meminta siswa untuk mengisi LKM secara individu, dan kelompok serta mendiskusikan hasil kerjanya dengan anggota kelas atau kelompok lain. Hanya kegiatan presentasi yang tidak sempat dilaksanakan pada kegiatan pascamenyimak, karena jam puasa yang dikurangi 20 menit dari jam selain bulan Ramazan.

Berdasarkan hasil analisis data siklus I dilakukan refleksi. Refleksi dilaksanakan terhadap pembelajaran menyimak apresiatif dengan strategi belajar kooperatif. Pada data tindakan dapat dihasilkan refleksi sebagai berikut.

1) Tahap perencanaan peningkatan kemampuan menyimak apresiatif dengan strategi belajar kooperatif telah dibuat oleh dosen dan didiskusikan dengan peneliti. Perencanaan pembelajaran siklus I tersebut masih perlu dipertahankan untuk digunakan pada siklus II. Namun masih ada hal-hal yang perlu mendapat perhatian pada siklus II, yaitu dosen sebaiknya memberikan motivasi kepada siswa untuk melakukan diskusi yang tidak hanya dengan kelompok pasangannya saja, tetapi juga pada kelompok kelas, dan dosen hendaknya berkeliling kelas untuk memberikan bantuan kepada mahasiswa jika diperlukan, dan waktu untuk diskusi masih terlalu sempit, sehingga perlu ditambah.

2) Dalam proses pembelajaran menyimak apresiatif dengan strategi belajar kooperatif diketahui bahwa:

a. Kegiatan pembelajaran berjalan baik, menarik, dan suasana kelas sangat hidup. Mahasiswa termotivasi dalam mengikuti kegiatan pembelajaran dan saling bekerja sama.

b. Evaluasi proses direkam melalui rambu-rambu proses menyimak, sedang apresiasi hasil dilaksanakan dengan mengisi LKM. Pelaksanaan evaluasi proses membantu dosen dalam mengetahui kemajuan dan kesulitan yang dialami mahasiswa. Pada siklus II pelaksanaan soal esai tetap di- 
gunakan, karena terbukti dapat meningkatkan daya apresiasi mahasiswa.

c. Kegiatan pembelajaran dapat dikatakan berhasil, dan hanya sebagian kecil mahasiswa yang kelihatan kurang aktif dalam pembelajaran. Hal yang perlu diperhatikan pada siklus II agar semua mahasiswa aktif dalam melaksanakan kegiatan pembelajaran.

d. Waktu presentasi hasil tidak ada, sehingga hasil kerja hanya dikumpulkan saja.

\section{Pembelajaran Menyimak Apresiatif Cerita Pendek dengan Strategi Belajar Kooperatif Siklus II}

Sebelum melaksanakan tindakan, peneliti dengan dosen mata kuliah menyimak di Jurusan Sastra Arab Fakultas Sastra secara kolaboratif menyusun rencana pembelajaran. Perencanaan tersebut disusun dan dikembangkan berdasarkan tujuan pembelajaran menyimak yang tertuang dalam katalog Jurusan Sastra Arab Fakultas Sastra tahun 2003. Perencanaan pembelajaran tersebut terdiri atas (1) menetukan tujuan pembelajaran, (2) memilih materi, (3) menentukan kegiatan belajar mengajar, dan (4) menyusun alat penilaian.

Proses pembelajaran ini mengambil tujuan pembelajaran umum mengapresiasi cerita pendek terhadap tokoh-tokoh cerita, alur, latar, dan suasana. Alokasi waktu adalah 2 jam pertemuan (80 menit) yang difokuskan pada kegiatan pramenyimak,menyimak, dan pasca menyimak.

Pelaksanaan pembelajaran menyimak apresiatif cerpen dengan strategi belajar kooperatif di Jurusan Sastra Arab Universitas Negeri Malang untuk siklus II dilaksanakan pada hari Senin, tanggal 2 Oktober 2006 pukul 10.20 -12.00.
Sesuai dengan perencanaan yang telah diuraikan di atas, pelaksanaan pembelajaran terbagi atas tiga tahap, yaitu tahap pra-menyimak, menyimak, dan pascamenyimak.

Pembelajaran pada siklus II sudah menunjukkan keberhasilan. Hal ini terlihat pada nilai rata-rata mahasiswa yang tinggi, yaitu: 9,3. Setelah melihat hasil pembelajaran di atas, peneliti dan dosen menyimpulkan bahwa pembelajaran pada siklus II ini sudah sempurna.Karena hasil kerja mahasiswa sudah sangat baik, begitu juga proses pembelajarannya. Mahasiswa sudah aktif dalam berdiskusi dan menggunakan waktu sebaik mungkin. Dosen sudah melaksanakan rencana pembelajaran sebaikbaiknya.

Keberhasilan tindakan siklus II diamati selama proses pelaksanaan tindakan dan setelah tindakan. Fokus pengamatan adalah perilaku dosen dan mahasiswa dengan menggunakan pedoman observasi dan catatan lapangan. Adapun aspek yang diamati adalah aktivitas dosen dan mahasiswa dalam proses pembelajaran yang terdiri atas 3 tahapan, yaitu tahap pramenyimak, menyimak, dan pascamenyimak.

Sesuai dengan hasil observasi yang dilaksanakan terhadap pembelajaran Menyimak Apresiatif siklus kedua, dapat dideskripsikan sebagai berikut:

1. Aktivitas dosen, pada kegiatan pramenyimak adalah menjelaskan tujuan pembelajaran, serta membangkitkan skemata mahasiswa sambil bertanya jawab. Dosen dapat menarik minat mahasiswa dengan bertanya jawab tentang judul cerita. Dosen menayangkan cerita yang sudah disiapkan. Kegiatan selanjutnya dosen meminta siswa untuk mengisi LKM secara individu, dan kelompok serta mendiskusikan hasil kerjanya dengan anggota kelas atau kelom- 
pok lain. Kemudian dosen meminta dua kelompok mewakili kelas untuk membacakan hasil kerjanya.

2. Aktivitas mahasiswa. Mahasiswa antusias untuk memberi tanggapan pada kegiatan pramenyimak. Mahasiswa aktif menyimak pengarahan dosen. Pada kegiatan diskusi kelas, mahasiswa aktif bertanya dan menjawab pertanyaan baik dari anggota kelompoknya, maupun dengan kelompok lain. Mahasiswa aktif mendengarkan ketika salah satu anggota kelompok membaca hasil pekerjaan kelompok, dan ketika guru memberikan klarifikasi dan tanggapan.

\section{Perencanaan Pembelajaran Menyimak Apresiatif dengan Strategi Belajar Ko- operatif}

Rencana pembelajaran merupakan hal yang sangat penting untuk mengarahkan proses pembelajaran, karena model yang ditampilkan pengajar dapat menggugah skemata siswa dalam memahami materi pembelajaran. Berdasarkan rancangan yang dibuat melalui proses diskusi dan revisi dan disesuaikan dengan teori-teori pembelajaran yang relevan, maka setiap tahap pembelajaran seharusnya memperhatikan langkah-langkah yang telah ditetapkan. Hasil penelitian menunjukkan bahwa rancangan yang disusun sangat berpengaruh terhadap keaktifan mahasiswa dalam menyimak. Keaktifan mahasiswa tersebut didukung oleh kesesuaian rencana pembelajaran dengan kebutuhan pembelajar, tujuan pembelajaran, serta kondisi belajar yang diinginkan. Kualitas aktivitas mahasiswa nampak pada munculnya indikator yang telah dijadikan rambu-rambu dalam menyusun rencana pembelajaran.

Perencanaan pembelajaran yang disusun pada siklus 1 dan 2 menggunakan format yang sama, namun pada siklus II diadakan perbaikan serta pengem- bangan dan penyempurnaan berdasarkan hasil refleksi dan temuan penelitian pada siklus I. Yaitu ditambahnya waktu untu pelaksanaan tahap pascamenyimak yang semula hanya diberi waktu 20 menit, diperbanyak menjadi 30 menit. Hal ini dilakukakan mengingat waktu untuk berdiskusi dan menyajikan hasil kerja memerlukan waktu yang banyak. Dan kegiatan pada tahap ini merupakan inti pembelajaran kooperatif. Mahasiswa saling berbagi pengetahuan dalam menyelesaikan tugas dan saling bekerja sama. Sebagaimana hakikat pembelajaran kooperatif yaitu strategi pembelajaran yang mengacu pada suasana di mana siswa bekerja bersama dalam kelompok kecil saling membantu dalam belajar (Nur \& Wikandari, 2000:25). Rencana pembelajaran merupakan acuan dalam pelaksanaan pembelajaran, oleh sebab itu rencana pembelajaran harus disusun dengan baik, dan memeprhatikan faktor pembelajaran yang aka dilaksanakan. Dimyati dan Mujiono (1999:134) menjelaskan bahwa dalam merancang pembelajaran, seorang guru harus memperhatikan faktor-faktor (1) karakteristik tujuan, (2) karakteristik materi pembelajaran yang meliputi tujuan, isi pelejaran, urutan dan cara mempelajarinya, (3) karakter siswa mencakup karakter prilaku, usia, jenis kelamin, (4) karakter lingkungan pembelajaran, meliputi kuantitas prasarana, jam pertemuan, dan (5) karakteristik pengajar, meliputi filosofis dan pengalaman kependidikan.

Berdasarkan hasil penelitian, dosen telah melaksanakan pembelajaran dengan baik sesuai dengan rencana pembelajaran yang telah disusun. Hal ini sesuai dengan pendapat Hamalik (2001:135) bahwa perencanaan mengajar dibuat untuk membantu dosen mengenal kebutuhan siswa, minat siswa, dan mendorong memotivasi belajar siswa. Komponen-komponen yang termuat 
dalam rencana pembelajaran meliputi: (1) Topik (2) tujuan pembelajaran (3)kegiatan belajar-mengajar, dan (4) evaluasi.

Dalam mencapai tujuan pembelajaran khusus dosen menggunakan strategi belajar kooperatif model struktural dengan teknik think pair share melalui tiga tahapan yaitu tahap pascamenyimak, menyimak, dan pascamenyimak.

Berdasarkan rencana pembelajaran yang dibuat dosen secara kolaboratif dengan peneliti melalui proses modifikasi dan disesuaikan dengan teori-teori belajar kooperatif, setiap tahap terbukti efektif. Keefektifan tersebut dapat dilihat dari kesesuaian rencana pembelajaran dengan kebutuhan pembelajaran, baik dari segi dosen maupun mahasiswa, tujuan pembelajaranmaupun kondisi pembelajaran yang direncanakan.

\section{Pelaksanaan Pembelajaran Menyimak Apresiatif dengan Strategi Belajar Ko- operatif}

Pelaksanaan pembelajaran yang dibahas meliputi bahasan tentang aktivitas dosen dan aktivitas mahasiswa, yang kedua-duanya mencakup kegiatan pra-menyimak, menyimak, dan pascamenyimak.

Langkah-langkah pramenyimak sebagaimana disebutkan sangat membantu peningkatan perhatian mahasiswa untuk lebih siap dalam melaksanakan kegiatan menyimak. Mahasiswa dilibatkan dalam kegiatan Tanya jawab tentang judul cerita, dan diminta untuk memperkirakan isi cerita. Kegiatan seperti ini merupakan kegiatan untuk membangun skemata mahasiswa sehingga lebih termotivasi dan siap dengan kegiatan selanjutnya.

Piaget (Cahyono, 1993:16) menyatakan bahwa pembangkitan skemata berfungsi sebagai (1) tempat atau alat untuk mengasimilasi pengetahuan baru, (2) berguna bagi penulis untuk mengetahui hal-hal penting, (3) memperjelas kesimpulan, (4) membantu penulis mengembangkan tulisannya, (5) membantu dalam mengingat pengetahuan baru yang diperoleh. Hal ini sejalan dengan pendapat Person (Burns dkk. 1996:207) yang menyatakan bahwa pembangkitan skemata yang ditawarkan dapat menyebabkan terjadinya proses penghubungan antara informasi tekstual dan pengetahuan yang telah dimiliki siswa.

Langkah-langkah kegiatan pramenyimak tersebut sesuai dengan pendapat Syafi'ie (1999:13) yaitu bahwa kegiatan belajar harus dilakukan melalui tahapan berikut. (1) guru menyiapkan pengetahuan awal siswa mengenai pelajaran, (2) guru menjelaskan kegiatan pembelajaran yang akan dilakukan, (3) guru menyajikan bahan, dan (4) guru membagi kelas dalam kelompok-kelompok.

Sementara itu De Poter, dkk. (2001:84) menyatakan bahwa pada kegiatan awal pembelajaran guru perlu mengikutsertakan emosi siswa. Guru perlu mengetahui minat, hasrat dan pikiran siswa, dan jika siswa sudah merasa berminat tentang pembelajaran, maka pembelajaran akan berjalan dengan baik dan tujuan tercapai.

Setelah membangkitkan skemata mahasiswa, dosen menyampaikan tujuan pembelajaran. Penyampaian tujuan pembelajaran sangatlah penting agar mahasiswa dapat mengetahui dan memahami apa yang harus dipelajarinya.

Selanjutnya dosen membentuk kelompok belajar secara hiterogen. Berdasarkan pengamatan belajar kelompok dengan keanggotaan yang hiterogen, dapat memberikan manfaat positif dalam menyelesaikan tugas-tugas yang harus diselesaikannya dengan bekerja sama, rasa tanggung jawab dan tidak memen- 
tingkan diri sendiri. Hal ini sesuai dengan pendapat Coelho (1992:131) bahwa salah satu prinsip pembelajaran dengan strategi belajar kooperatif adalah prinsip akuntabilitas atau tanggung jawab. Setiap siswa bertanggung jawab secara pribadi terhadap kelompok dan guru untukl menyelesaikan tugas atau bagian tugasnya sendiri, dan untuk membantu siswa lain.

Sesuai dengan kondisi kelas pembelajaran menyimak di laboratorium bahasa, yang mengharuskan mahasiswa menggunakan seperangkat alat dan tidak bias digeser-geser,maka pembentukan kelompok ditentukan, dengan anggota 2 atau 3. Shepardon (Ghazali, 2002:124) menyatakan bahwa dengan kelompok kecil, siswa dengan hambatan mental, pemalu, atau kurang berinisiatif, dapat meminta bantuan kepada anggota lainnya, atau secara kebetulan akan terdorong aktif dalam proses belajar kelompok.

Setelah pembagian kelompok, dosen menjelaskan prosedur pelaksanaan kerja kelompok, yang meliputio diskusi dengan pasangannya, dan diskusi kelas. Pemberian penjelasan dan arahan prosedur pelaksanaan belajar dengan strategi belajar kooperatif pada tahap pramenyimak ini sejalan dengan pernyataan Eanes (1997:549) bahwa pemberian instruksi instruksi lisan atau tertulis penting disampaikan pada awal pembelajaran.

Setelah tahap pramenyimak dilaksanakan, dosen memutar CD cerita yang dilaksanakan secara bertahap. Setiap pemutaran yang memakan waktu kira-kira 7-10 menit, dosen menghentikan tayangan dan memberikan kesempatan mahasiswa untuk menggali informasi atau pemahamannya terhadap cerita yang telah disimaknya. Melalui kegiatan diskusi ini situasi belajar kooperatif diciptakan yaitu suatu kondi- si yang mampu memberikan kesempatan yang merata pada semua mahasiswa untuk bertanya dan berpendapat. Pada siklus I fenomena siswa pasif masih ditentukan, penyebab kepasifan mahasiswa antara lain karena hambatan mental, pemalu, dan kurang berinisiatif.

Untuk membantu mahasiswa dalam mengapresiasi cerita pendek dosen memyiapkan lembar kerja mahasiswa sebagai panduan proses pembelajaran atau proses mengapresiasi cerita. Burns, dkk. (1996:488) menyatakan bahwa panduan belajar merupakan lembar kerja yang disiapkan guru untuk membantu memandu proses pembelajaran dan untuk mengurangi kesulitan-kesulitan pemahaman. Panduan belajar dapat berisi pertanyaan-pertanyaan tentang isi cerita dan unsur-unsurnya. Pertanyaan itu digunakan untuk memandu proses menyimak, sehingga mahasiswa memperoleh pemahaman dan dapat mengapresiasi cerita dengan baik melalui belajar bersama. Hal ini sesuai dengan pendapat Eggen (1996:279) yang menyatakan bahwa belajar kooperatif dapat memfungsikan siswa untuk belajar dan mengajar.

Kegiatan pascamenyimak diawali dengan kegiatan diskusi antar kelompok, kemudian dilanjutkan dengan pengisian lembar kerja mahasiswa dan presentasi hasil dari wakil kelompok, untuk merefleksikan pemahaman mahasiswa terhadap unsur cerita. Mahasiswa dilatih merefleksikan pemahamannya melalui kegiatan menulis sesuai dengan pertanyaan-pertanyaan yang ada pada lembar kerja mahasiswa. Berkaitan dengan itu Rhodes dan Marling (1988:193) menyatakan bahwa tujuan kegiatan pascamenyimak adalah (1) mendorong siswa untuk merefleksikan apa yang dipelajarinya dari sebuah teks atau cerita; (2) memperluas pemahaman siswa terhadap teks atau cerita yang di- 
baca atau disimak; (3) membantu siswa menghubungkan teks atau materi yang disimak dengan teks atau cerita yang pernah dilihat atau disimak.

Refleksi sikap dan minat mahasiswa terhadap unsur-unsur cerita menunjukkan bahwa terjadi keterlibatan mental mahasiswa terhadap cerita yang diapresiasi. Aspek emosi dan perasaan mahasiswa ikut terlibat aktif. Hal itu ditunjukkan dengan adanya kesadaran mahasiswa akan masyarakat yang tercermin dalam cerita, berupa kemampuan menilai baik dan buruknya karakter cerita, dan mampu menghubungkan nilai-nilai kehidupan di masyarakat.

Keberhasilan proses pembelajaran apresiasi cerita disamping ditentukan oleh adanya pemahaman perkembangan aspek kognitif dan psikomotorik juga ditentukan oleh perkembangan aspek afektif siswa. Hal ini sesuai dengan pendapat Bloom (dalam Depdiknas, 2003:113) bahwa ranah afektif mencakup lima hal yaitu: (1) sadar akan situasi, fenomena, masyarakat, dan objek alam sekitar; (2) responsif terhadap stimulus yang terdapat dalam masyarakat; (3) mampu menilai baik dan buruknya sesuatu; (4) mampu mengorganisasikan nilai-nilai tentang suatu sistem, dan (5) mampu menentukan hubungan di antara nilai-nilai yang ada.

Pada siklus II fenomena kepasifan mahasiswa dapat dikurangi, dengan cara dosen menunjuk langsung pada mahasiswa yang pasif untuk bertanya dan berpendapat serta mengomentari pendapat temannya.

Ketercapaian pembelajaran menyimak dengan strategi belajar kooperatif sebagaimana disebutkan telah dapat dibuktikan dengan nilai yang dicapai oleh mahasiswa. Nilai yang dicapai mencapai taraf keberhasilan sangat baik. Hal ini sungguh merupakan kemajuan yang sangat menggembirakan meng- ingat selama ini matakuliah menyimak merupakan mata kuliah yang kurang disukai karena keterbatasan kosakata yang dimiliki mahasiswa, dan aspek strategi pembelajaran yang monoton sehingga mahasiswa kurang termotivasi untuk mengikuti perkuliahan menyimak (Nurhidayati, 2003).

Aktivitas mahasiswa pada saat mengikuti pembelajaran juga mengindikasikan bahwa mahasiswa sangat bersemangat untuk mengerjakan tugas tugas yang diberikan dalam bentuklembar kerja mahasiswa. Materi atau topik cerita juga sangat disukai, karena menyangkut kisah percintaan antara seorang pangeran dan Putri Salju yang berakhir dengan bahagia.

Pada kegiatan menyajikan proses apresiasi mahasiswa merasa senang dan termotivasi. Dimyati dan Mujiono (1999:85) menjelaskan bahwa motivasi sangat penting bagi siswa dalam belajar, yaitu (1) menyadarkan kedudukan awal belajar, proses belajar, dan hasil belajar, (2) menginformasikan tentang kekuatan dalam usaha belajar, (3) mengarahkan pada kegiatan belajar, (4) membesarkan semangat belajat, dan (5) menyadarkan perjalanan belajar.

Melalui pembelajaran kooperatif mahasiswa menjadi aktif bertanya jawab baik dilakukan bersama teman sekelompok maupun teman sekelas, dan juga dengan dosen. Hal ini sesuai dengan pendapat Purwo (1997:29-30) yang berpendapat bahwa siswa pada hakikatnya adalah peserta aktif dan memiliki daya kreatif yang dapat dikembangkan lewat kegiatan berinteraksi.

Hal ini sejalan dengan pendapat Nur \& Wikandari (2000:8) bahwa siswa lebih mudah menemukan dan memahami konsep-konsep yang sulit jika mereka saling mendiskusikan masalah tersebut dengan temannya. Siswa saling membantu memcahkan masalah-ma- 
salah yang komplek dan penggunaan kelompok sejawat untuk memodelkan cara berfikir yang sesuai dan saling mengemukakan dan meluruskan kekeliruan pengertian atau miskonsepsi di antara mereka sendiri

\section{Simpulan}

Berdasarkan hasil penelitian dapat disimpulkan bahwa pelaksanaan pembelajaran menyimak apresiatif dengan strategi belajar kooperatif dapat dilaksanakan dengan hasil yang sangat efektif. Dosen telah membuat rencana pembelajaran dan mendiskusikannya dengan peneliti. Rencana pembelajaran yang sudah disepakati dilaksanakan sesuai dengan rambu-rambu yang ada, khususnya pada tahap siklus II, sedang pada siklus I masih terjadi kekurangan waktu yaitu ditiadakannya proses presentasi hasil diskusi. Hal ini dilakukan karena selain waktu yang tersedia pada bulan puasa yang berkurang dari harihari di luar puasa juga karena mahasiswa masih perlu waktu yang banyak untuk diskusi dan menjawab lembar kerja mahasiswa.

Pada tahap pra-menyimak dosen telah berhasil membangkitkan minat mahasiswa untuk menyimak cerita yang akan ditayangkan melalui kegiatan tanya jawab dan pemberian informasi singkat mengenai topik cerita, disamping itu dosen juga menjelaskan tentang tujuan pembelajaran dan langkah-langkahnya sehingga mahasiswa dapat dengan jelas memahami tugas yang akan dilaksanakan.

Pada tahap menyimak dosen telah berusaha membangkitkan minat dan perhatian mahasiswa dalam menyimak dan mengurangi kejenuhan dan keletihan menyimak cerita yang terlalu panjang. Dosen menayangkan cerita dengan proses bertahap yaitu berkisar antara 10-15 menit. Pada saat itu mahasiswa diberi kesempatan untuk berdiskusi dan memikirkan jawaban soal-soal yang ada pada lembar kerja mahasiswa.

Pada tahap pasca-menyimak dosen memberi kesempatan pada mahasiswa untuk berdiskusi dengan kelompoknya kembali dan berdiskusi dengan teman sekelas. Hasil dari kegiatan pembelajaran dengan strategi belajar kooperatif ini dapat ditunjukkan melalui hasil rata-rata nilai mahasiswa yang cukup tinggi, yaitu di atas 90, baik pada siklus I maupun kedua, dan keaktifan mahasiswa yang lebih besar dari pada keaktifan yang ditunjukkan pada siklus I.

Berdasarkan hasil penelitian maka dapat disimpulkan bahwa strategi belajar kooperatif sangat efektif untuk meningkatkan kemampuan mahasiswa dalam menyimak apresiatif baik pada tahap pra-menyimak, menyimak, dan pascamenyimak.

\section{UCAPAN TERIMA KASIH}

Artikel ini diangkat dari penelitian mandiri swadana yang dilaksanakan pada tahun 2010. Ucapan terima kasih disampaikan kepada mitra sejawat yang telah membantu kegiatan verifikasi dan triangulasi data dan hasil penelitian.

\section{DAFTAR RUJUKAN}

Aminuddin. 2000. Metasemiotik sebagai Dasar Signifikasi Teks Sastra. Dalam Rahayu S. hidayat (Ed) Semiotik. Jakarta: Universitas Indonesia Jakarta.

Bogdan \& Biklen. 1982. Qualitative Research for Education: An Introduction to Theory and Methods. Boston: Allyn aand Bacon Inc.

Burns, P.C., Betty, d. D. dan Elinor, P. R. 1996. Teaching reading in Todays elementary school. New York: Bos- 
ton Toronto.

Cahyono, B.Y. 1992/1993. Aplikasi Teori Skemata Struktur Teks dan Metakognitif pada Pengajaran Membaca Bahasa Inggris. Malang: Proyek Operasi dan Perawatan Fasilitas.

Cahyono, B.Y. 1997. Pengajaran Bahasa Inggris: Teknik, Strategi, dan Hasil Penelitian. Malang: Penerbit IKIP Malang.

Coelho, Elizabeth. 1992. Jigsaw: Inte grating Language and Content. Dalam: Carolyn Kessler (Ed). Cooperative Language Learning: A. Teacher's Resourche Book. Engelwood Cliffs, New Jersey: Prentice Hall Regents.

De Poter, Bobbi, Hernachei, Mike, Singer-Nourie Sarah. 2001. Quantum Teaching. Bandung: Kaifa.

Dimyati \& Mujiono.1999. Belajar dan Pembelajaran. Jakarta: Depdikbud.

Ghazali, Abd. Syukur. 2002. Strategi Belajar Kooperatif dalam Belajar Mengajar. Dalam: Sumber Belajar: Kajian Teori dan Aplikasi. Nomor 1 Tahun 8.

Hamalik, O. 2001. Proses Belajar Mengajar. Jakarta: Bumi Aksara.

Kemmis, S. dan MC. Taggart, R. 1988. The Action Research Planner. Victoria: Deaken University Press.

Luxemburg, Janvan, Bal M., weststeiju, Willem, G. 1989. Tentang Sastra. Jakarta: Intermasa.

MC Niff, J. 1992. Action Research: Principles and Practise. London: Macmillan Education Ltd.

Miles, M.B. \& A.A. Huberman. 1992. Analisis Data Kualitatif. Terjemahan Rohendi rohedi. Jakarta: Universitas Indonesia Press.
Moleong, Lj. 1995. Metodologi Penelitian Kualitatif. Bandung: PT Remaja Rodakarya.

Nurhadi, Yasin, dan Senduk. 2004. Pembelajaran Kontekstual dan Penerapannya dalam KBK. Malang: Penerbit Universitas Negeri Malang.

Nurhidayati, 2003. Jenis dan Sebab Kesulitan yang Dihadapi Mahasiswa dalam Menyimak Teks Bahasa Arab. Tesis tidak diterbitkan. Malang: Program Pascasarjana Universitas Negeri Malang.

Nur, Mohamad \& Wikandari Prima Retno. 2000. Pengajaran Berpusat kepada Siswa dan Pendekatan Konstruktivis dalam Pengajaran. Surabaya: Pusat Studi Matematika dan IPA Sekolah Universitas Negeri Suarabaya.

Purwa, B. K. 1997. Pokok-Pokok Pengajaran Bahasa dan Kurikulum 1994 Bahasa Indonesia. Jakarta: Depdikbud.

Rozaq, A. 2002. Pengefektifan Pembelajaran appresiasi Cerita Pendek dengan Pendekatan Interaksi Dinamis Siswa Kelas II SLTPN I Tumpang Kabupaten Malang. Tesis tidak diterbitkan. Malang: Program Pasca Sarjana Universitas Negeri Malang.

Syafi'ie, I. 1999. Diagnosis Kesulitan Belajar Bahasa. Dalam Bahasa dan Seni. Februari No:I

Syafi'ie, I. 1999. Pengajaran Membaca di Kelas-Kelas Awal Sekolah Dasar. Pidato Pengukuhan Guru Besar dalam Bidang Pengajaran Bahasa Indonesia pada Fakultas Pendidikan Bahasa dan Seni. Disampaikan pada sidang senat terbuka Senat Universitas Negeri Malang, 7 Desember. 